\title{
Degree of Availability of Good Teacher Characteristics among the English Language (EL) Teachers of Basic Stage Schools from Their Principals' Views in Tafila Governorate
}

\author{
Attalla Alroud ${ }^{1, *} \&$ Mohammad Qomoul ${ }^{1}$ \\ ${ }^{1}$ Department of Curricula and Instruction, Tafila Technical University, Jordan \\ *Corresponding author: Department of Curricula and Instruction, Tafila Technical University, Jordan. Tel: \\ 962-774-686-180-0962 E-mail: atallah_roud@yahoo.com
}

Received: February 22, 2017

Accepted: March 3, 2017 Online Published: April 18, 2017

doi:10.5430/wje.v7n2p65

URL: https://doi.org/10.5430/wje.v7n2p65

\begin{abstract}
The study aimed to investigate the Degree of Availability of Good Teacher Characteristics Among English Language (EL) Teachers of Basic Stage Schools from Their Principals' views in Tafila Governorate. This could be achieved through answering the following questions:

1-What is the degree of availability of good teacher characteristics among English Language (EL) teachers of basic stage schools from their principals' views in Tafila Governorate?

2-Are there statistically significant differences attributed to the variables of teacher's gender, and experience?

The sample consisted of (89) male and female teachers which forms about 55\% chosen randomly from the population of the study.

The results showed that there is a significant difference attributed to gender and no significant difference attributed to experience or to the interaction of experience and gender. The study found some recommendations.
\end{abstract}

Keywords: characteristics; principals; good teacher

\section{Introduction and Background}

The process of teaching and learning is considered as sophisticated task since it deals with human mind. The theories pertaining this process relatively agreed that the three most important elements are teacher, student, and curriculum. Some theories considered the teacher as the core of the process. Anyhow; the role of the teacher cannot be ignored and for that there must be special characteristics for teachers in general and for EL teachers in particular as it is a foreign language(EL) in Jordan.

Borg(2006) found that the teachers of EL were different from other teachers in nature of the subject, the content of teaching, the methodology, the teacher-student relationship. And the native-nonnative contrast of speakers. The question of who is a good teacher was answered by most of those who interested in this topic. They agreed that a good/great teacher in most cultures should be held to a high standard of knowledge and character.

Zhang and Watkins(2007) stated that the concept of a good teacher has been explored from number of perspectives over the course of decades, yet most of these investigations have been conducted in Western contexts and have tended to explore teachers across disciplines.

Since principals are considered as permanent supervisors, and in some countries they are responsible for employing teachers, they can evaluate teachers and judge on their characteristics and employ them taking into account the qualities of a good teacher upon their views.

Many experts and specialists in this field indicated the views of principals in evaluating teachers through standards and criteria relating to instructional and administrative domains.

Kalebic(2005) stated that a language teacher should possess fourteen competences. Those characteristics reported to highly valuable for a beginning language teacher were: linguistic and communicative competence; communication 
and presentation skills; ability to motivate learners for learning; ability to choose appropriate teaching strategies; ability to deal with unpredictable situations and to maintain discipline; ability to plan the lessons; ability to organize learning activities; ability of pedagogical action; ability to create friendly atmosphere in the classroom; ability to respond to learners abilities and needs; knowledge about teaching strategies; knowledge about the culture and literature of the target language; ability to assess learner language competence; and knowledge of methods and theoretical concepts in (EL) teaching.

Hoy and Hoy(2012) mentioned that instructional leadership can include a range of activities involving staff development, curriculum development, student assessment and analysis, and evaluation and individualized feedback.

Dunton(2001) stated that principals also report preferences for teachers with particular teaching skills, teaching philosophies, knowledge, and ability to work well with others. Rutledge, Harris, and Ingle(2010) found that school administrators valued teachers with strong teaching skills(e.g., establishing positive classroom climate) and subject matter knowledge. Meanwhile, Mertz(2010) found that principals failed to consider factors that directly influenced student achievement, such as applicant subject matter knowledge or pedagogical ability to teach subject matter.

\section{Literature}

Koutsoulis(2003) identified 94 characteristics of effective teachers in25 high school in Cyprus. He classified those characteristics into three categories: human characteristics including the ability to show understanding and teacher friendless; communication characteristics regarding to the ability to communicate with students and to handle teacher-student relations; and teaching and production characteristics such as making lessons interesting and motivating and teachers' subject matter knowledge. The findings showed that the students of low achieving endorsed more human and communication characteristics than students with high achievement, whereas the high achievement students acknowledged more teaching and production characteristics.

Park and Lee (2006) conducted a study to investigate the characteristics of effective EL teachers. The sample consisted of 169 teachers and 339 students in a high school in Korea. The sample was provided with a self-report questionnaire to answer consisting of three categories: English proficiency, pedagogical knowledge, and socio-affective skills. The results indicated that the teachers perceived significantly different characteristics than the students in all categories ranking English proficiency the highest in contrast with students who ranked pedagogical knowledge the highest. The findings also showed that the high achieving students reported different characteristics than low achieving students in pedagogical knowledge and socio- affective skills. The male students demonstrated different characteristics from the female students in socio-affective skills.

Homa and Karim(2009) conducted a study to identify the characteristics of an effective EL teacher as perceived by Iranian teachers and students. The sample consisted of 59 teachers and 215 students of English at universities, high schools, and language institutes in Iran. The results indicated that teachers agreed more strongly than students that an effective EL teachers should assign homework and integrate group activities into the classroom. There was significant difference in opinions included preparing the lesson well, using lesson plans, assessing students' learning. On the opposite of teachers, students agreed that teaching English in Persian as native language of learners was one of the prominent characteristics of an effective EL teacher. The qualitative analysis indicated that teachers perceived the features like mastery of foreign language, good knowledge of pedagogy, use of techniques and methods, and good personality to make an effective EL teachers, whereas, students gave more weight to characteristics relating to a teacher's personality and the way he behaves towards his students.

Al-Maqtri (2013) conducted a study to investigate the characteristics of a good EL teacher in as perceived by Saudi and Yemeni college students of English. The samples were selected purposively from students of English in the two countries. Data collection was through asking an open-ended question to list the qualities of the good English teacher. The findings showed that there was disagreement among the groups for the priority of the four categories that the researcher defined (English proficiency, pedagogical knowledge, socio-affective skills, and organization and communication), but socio-affective category was characteristic of all the samples preponderated by Yemeni samples. The qualities included in socio affective category were: a good English teacher is patient, relaxed, good tempered, fair, helpful, encouraging, respectful, kind, loving and caring. The results also indicated that there were no major differences regarding gender and level. Saudis wanted teacher to use translation, give simple tests and assignments, and want teachers to give them an opportunity to talk to them.

Harris, Rutledge, Ingle, and Thompson(2010) interviewed 30 principals from a mid-sized Florida school district to classify the preferred characteristics of teachers. They classified teachers into two categories: professional category 
including (strong teaching skills, experience, knowledge of subject matter, intelligence, certification, and education) and personal category including (caring, motivated, enthusiastic, works well with others, creative, cooperative, organized, thoughtful, and communication skills). The results indicated that the most important characteristics of an applicant that principals considered were strong teaching, caring, and knowing the subject, followed by working well with others, experience, enthusiasm, and communication skills. The most important characteristic in professional category was caring, and it came as a second important characteristic among the two categories.

Engle(2013) surveyed 368 principals to rate and rank their preferences for teacher qualities from a list including 15 characteristics in Chicago Public Schools(CPS). The results indicated that the rates of the principals regarding the qualities of a good teacher came as follows: the extremely important ones were, enthusiasm for teaching, classroom management skills, and the ability to provide a positive role model. The ranks of the principals among the most important characteristics were: classroom management skills, the ability to create a fun and stimulating learning environment, ability to increase student achievement in ways that will not necessarily show up on standardized.

Chireshe(2011) indicated the qualities of effective and ineffective lecturers from the students' perspectives by using the design of qualitative survey. The sample who answered the questionnaire consisted of (77) students. The results showed that the effective lecturers were well organized, always involved students, friendly and readily available, in addition to that they should be fair in scoring. On the other hand, it was found that ineffective lecturers did not plan their lectures, came late for lectures, frightened students, did not involve students, and bias in scoring.

\section{Methodology:}

\subsection{Problem Statement}

As mentioned previously, the teacher is considered as one of the most important component in the process of teaching and learning, so his characteristics will influence either positively (if good) or negatively (if not good) the students' learning and achievement. Since the researchers are professors in methods of teaching English, they noticed that the students who join the university are poor in English Language which makes them try to investigate the characteristics of the teachers in Tafila Directorate of Education. The problem may arise through answering the following questions:

1. What is the degree of availability of good teacher characteristics among the English Language (EL) teachers of basic stage schools from their principals' views in Tafila Governorate?

2. Are there statistically significant differences attributed to the variables of teacher's gender, and experience?.

\subsection{Aim of the Study}

The study aimed to investigate the degree of availability of good teacher characteristics among the English Language (EL) teachers of basic stage schools from their principals' views in Tafila Governorate?

The aim could be achieved through answering the following questions:

1. What is the degree of availability of good teacher characteristics among the English Language (EL) teachers of basic stage schools from their principals' views in Tafila Governorate?

2. Are there statistically significant differences attributed to the variables of teacher's gender, and experience?.

\subsection{Significance of the Study}

The results of the study may help teachers to deduce the missed good qualities of themselves and try to develop those qualities as possible in order to reinforce the process of teaching and learning. In addition to that, principals can get a clear image that helps in assessing the qualities of their teachers.

\subsection{Design}

The descriptive research design is adopted for this study.

\subsection{Population of the Study}

The population of the study consisted of(160) English Language male and female teachers for the basic stage in Tafila Governorate schools.

\subsection{Sample of the Study}

The sample of the study consisted of (89) male and female teachers which forms about $55 \%$ chosen randomly from the population of the study as table(1)shows: 
Table 1. Sample of the Study

\begin{tabular}{llll}
\hline Gender & Experience & & \\
& $\mathbf{1 - 1 0}$ & $\mathbf{1 1} \mathbf{~ F}$ & Total \\
\hline male & 32 & 9 & 41 \\
female & 29 & 19 & 48 \\
Total & 61 & 28 & 89 \\
\hline
\end{tabular}

\section{7 Instrument}

After reviewing the related literature, the researchers developed an instrument consisted of two parts: part one is a personal demographic information, and part two is a questionnaire consisted of (35)items divided into (4) domains. Academic domain includes (14) items, personality domain (8) items, administrative domain (7), and social domain (6) items.

\subsection{Validity of the Instrument}

The instrument was distributed to a jury of experts in education at universities, principals, and supervisors of English Language. The notes of the jury taken into account and finally the modified copy was adopted.

\subsection{Reliability of the Instrument}

The reliability of the instrument and domains were computed using internal consistency (Chronbach Alpha) as table (2) shows;

Table 2. Reliability of the Study

\begin{tabular}{ll}
\hline Domain & Chronbach Alpha \\
\hline Academic Domain & .931 \\
Personality domain & .918 \\
Administrative domain & .896 \\
Social domain & .909 \\
Grand average & .968 \\
\hline
\end{tabular}

\section{Results of the Study}

1. For answering question 1 which states: What is the degree of availability of good teacher characteristics among the English Language (EL) teachers of basic stage schools from their principals' views in Tafila Governorate?

Means and standard deviations (SDs) for the entire tool domains were calculated using the following classification scale to describe the means: (1-2.33)low, (2.34-3.67)mid, and (2.68-5)high as table (3) shows;

Table 3. Means and Standard Deviations (SDs) for the Entire Tool Domains

\begin{tabular}{llll}
\hline No. of domain & Domain & Means & SDs \\
\hline 1 & Academic Domain & 4.138 & .908 \\
2 & Personality Domain & 4.147 & .771 \\
3 & Administrative Domain & 4.102 & .771 \\
4 & Social Domain & 3.711 & 1.234 \\
Grand average & & 4.060 & .743 \\
\hline
\end{tabular}

It is indicated that the grand average for the principals' estimations to EL teachers was high with a mean of (4.06) and SD of (.743). This result shows that the principals are convenient with the characteristics of their EL teachers. It is also observed that the principals' estimations to the teachers are high in all the domains included in the study tool. The means of domains came between (3.71-4.14). The highest domain was the teachers' personality with a mean of (4.14)and SD of (.771); whereas, the social domain came as the lowest with a mean of (3.71) and SD of (1.234). 
Regarding the results of items in each domain, means and SDs where computed as the following tables show;

Table 4. Means and SDs for the Items of Academic Domain

\begin{tabular}{llll}
\hline No. of item & Items/domain & Means & SDs \\
\hline 1 & Assesses the students work regularly & 4.204 & .832 \\
2 & Puts questions of tests with good characteristics & 4.179 & .805 \\
3 & Uses language in real life situations & 3.809 & .939 \\
4 & Uses technology in teaching & 3.662 & 1.021 \\
5 & Offers feedback to students & 4.146 & .819 \\
6 & Accepts students & 4.224 & .794 \\
7 & Considers individual differences & 4.112 & .858 \\
8 & Reinforces his/her students & 4.202 & .868 \\
9 & Masters English language well & 4.325 & .765 \\
10 & Involves all students in the class & 3.910 & .912 \\
11 & Varies his methods in teaching & 3.842 & .940 \\
12 & Is enthusiastic for his/her work & 3.865 & 1.109 \\
13 & Uses different teaching aids & 3.775 & .926 \\
14 & Prepares the lessons well & 4.202 & .908 \\
Academic Domain & & 4.138 & .908 \\
\hline
\end{tabular}

The figures in table (4) show that the grand average for the items as a whole was high with a mean of (4.138) and SD of (.908). The means of the items came between (3.66-4.32 for the items (4) which runs (uses technology in teaching) and item (9) which runs (masters EL well) successively. It is also observed that the means of the items of this domain are high except item (4) which states (uses technology in teaching) came mid with a mean of (3.66) and standard deviation of (1.021).

Table 5. Means and SDs for the Items of Personality Domain

\begin{tabular}{llll}
\hline No. of item & Items/domain & Means & SDs \\
\hline 15 & Pays attention to his /her appearance & 4.449 & .783 \\
16 & Behaves as a model for his/her students & 3.932 & 1.063 \\
17 & Behaves wisely with critical situations & 4.033 & 1.005 \\
18 & Respects the students & 4.236 & .904 \\
19 & characterized with patience is & 4.157 & .890 \\
20 & Has self-confidence & 4.292 & .855 \\
21 & Has balanced personality & 4.224 & 1.041 \\
22 & Tries to be innovative & 3.853 & 1.153 \\
Personality Domain & 4.147 & .771 \\
\hline
\end{tabular}

In table (5), the results show that the grand average of the items of the domain came high with a mean of (4.147) and SD of (.0771). The means of items came between (3.853-4.449) for item(22) which runs (tries to be innovative) and item (15) which states (pays attention to his appearance) successively.

The figures in table (6) show that, the grand average of the items of the domain was high with a mean of (4.102) and $\mathrm{SD}$ of (1.049). The means of the items are high. The lowest mean was(3.730) for item (25) which runs (participates with non-curriculum activities), and the highest mean was (4.269) for item (25) which states (is committed to work during the academic year). 
Table 6. Means and SDs for the Items of Administrative Domain

\begin{tabular}{llll}
\hline No. of item & Items/domain & Means & SDs \\
\hline 23 & Does all the administrative instructions & 4.123 & .914 \\
24 & Is committed to work during the academic year & 4.269 & 1.019 \\
25 & Participates with non- curriculum activities & 3.730 & 1.008 \\
26 & Manages the class time well & 4.112 & .970 \\
27 & Helps his/her principal in solving problems & 3.831 & .919 \\
28 & Solves the problems of the students in the classroom smoothly & 3.898 & 1.022 \\
29 & Is committed to the class time & 4.247 & .920 \\
Administrative Domain & 4.102 & 1.049 \\
\hline
\end{tabular}

Table 7. Means and SDs for the Items of Social Domain

\begin{tabular}{llll}
\hline No. of item & Items/Domain & Means & SDs \\
\hline 30 & Participates in his/her colleagues occasions & 3.842 & 1.054 \\
31 & Communicates with students' parents & 3.528 & 1.088 \\
32 & Participates in local society occasions & 3.505 & 1.023 \\
33 & Communicates with his/ her colleagues outside the school & 3.730 & .914 \\
34 & Maintains on customs and traditions of society & 3.898 & 1.034 \\
35 & Communicates with students outside school & 3.202 & .943 \\
Social Domain & & 3.711 & 1.234 \\
\hline
\end{tabular}

In table (7), the figures show that the grand average of the items was with a mean of (3.771) and SD of (1.234). The means of the items came between the highest item number(34) which states (maintains on customs and traditions of the society) with a mean of (3.898) and SD of (1.034) and the lowest item number (35) which runs (communicate with students outside school) with a mean of (3.202) and SD of (.934). For item (31) which runs (communicate with students' parents), it came mid with a mean of (3.528) and SD of (1.088). It is also noticed that item number (32) which states (participates in local society occasions) came mid with a mean of (3.505) and SD of (1.023).

Table 8. Means and SDs for the Domains According to Gender

\begin{tabular}{llll}
\hline Gender & Domain & Means & SDs \\
\hline male & Academic Domain & 3.882 & .914 \\
& Personality Domain & 4.048 & .755 \\
& Administrative Domain & 4.066 & 1.322 \\
& Social Domain & 3.731 & 1.593 \\
\multirow{3}{*}{ female } & Average total & 3.931 & .798 \\
& Academic Domain & 4.357 & .852 \\
& Personality Domain & 4.231 & .783 \\
& Administrative Domain & 4.133 & .755 \\
Grand average & Social Domain & 3.694 & .831 \\
\hline
\end{tabular}

It is noticed in table (8) that the estimations of principals for female teachers were higher than male teachers regarding the degree of availability of the characteristics of a good teacher in all the domains of the study except in social domain. 
For answering question number (2), Are there statistically significant differences attributed to the variables of teacher's gender, and experience?. The researchers used MANOVA to find out the significant differences attributed to the variables of gender and experience as table (9) shows:

Table 9. Post Comparisons for the Effect of Gender and Experience and the Interaction between Them for the Estimations of Principals to EL Teachers

\begin{tabular}{lllllll}
\hline Effect & & Value & F & Hypothesis df & Error df & Sig. \\
\hline gender & Pillai's Trace & .132 & $2.470 \mathrm{a}$ & 5.000 & 81.000 & .039 \\
& Wilks' Lambda & .868 & $2.470 \mathrm{a}$ & 5.000 & 81.000 & .039 \\
& Hotelling's Trace & .152 & $2.470 \mathrm{a}$ & 5.000 & 81.000 & .039 \\
Experience & Roy's Largest Root & .152 & $2.470 \mathrm{a}$ & 5.000 & 81.000 & .039 \\
& Pillai's Trace & .094 & $1.688 \mathrm{a}$ & 5.000 & 81.000 & .147 \\
& Wilks' Lambda & .906 & $1.688 \mathrm{a}$ & 5.000 & 81.000 & .147 \\
gender & Hotelling's Trace & .104 & $1.688 \mathrm{a}$ & 5.000 & 81.000 & .147 \\
Experience & Roy's Largest Root & .104 & $1.688 \mathrm{a}$ & 5.000 & 81.000 & .147 \\
& Pillai's Trace & .078 & $1.376 \mathrm{a}$ & 5.000 & 81.000 & .242 \\
& Wilks' Lambda & .922 & $1.376 \mathrm{a}$ & 5.000 & 81.000 & .242 \\
& Hotelling's Trace & .085 & $1.376 \mathrm{a}$ & 5.000 & 81.000 & .242 \\
& Roy's Largest Root & .085 & $1.376 \mathrm{a}$ & 5.000 & 81.000 & .242 \\
\hline
\end{tabular}

The figures in table (9) show the post comparisons of the differences in the principals estimations for the availability of the good teacher characteristics among the teachers of EL in Tafila Governorate. It is indicated that there are statistically significant differences at $(\alpha=0.05)$ in principals estimations for EL teachers attributed to the variable of gender and in favor of female teachers as table (8) showed.

Table 10. MANOVA for the Effect of Gender and Experience and the Interaction between Them for the Estimations of Principals to EL Teachers

\begin{tabular}{llllllll}
\hline Source & Dependent variable & $\begin{array}{l}\text { Type } \\
\text { sum } \\
\text { squares }\end{array}$ & $\begin{array}{c}\mathbf{1 1 1} \\
\text { of }\end{array}$ & df & $\begin{array}{l}\text { Mean } \\
\text { square }\end{array}$ & F & Sig. \\
\hline gender & Academic Domain & 4.010 & 1 & 4.010 & 5.306 & .024 \\
& Personality Domain & .183 & 1 & .183 & .308 & .580 \\
& Administrative Domain & .001 & 1 & .001 & .001 & .977 \\
& Social Domain & .002 & 1 & .002 & .001 & .972 \\
& Average total & .784 & 1 & .784 & 1.444 & .233 \\
Experience & Academic Domain & 2.130 & 1 & 2.130 & 2.818 & .097 \\
& Personality Domain & 1.123 & 1 & 1.123 & 1.889 & .173 \\
& Administrative Domain & 1.288 & 1 & 1.288 & 1.147 & .287 \\
& Social Domain & .084 & 1 & .084 & .053 & .818 \\
gender & Average total & 1.006 & 1 & 1.006 & 1.851 & .177 \\
Experience & Academic Domain & .523 & 1 & .523 & .691 & .408 \\
& Personality Domain & .151 & 1 & .151 & .253 & .616 \\
& Administrative Domain & .086 & 1 & .086 & .077 & .782 \\
& Social Domain & .025 & 1 & .025 & .016 & .900 \\
& Average total & .029 & 1 & .029 & .053 & .819 \\
\hline
\end{tabular}

Regarding to the experience of the teacher and the interaction between gender and experience, the figures in table (10) show that there are no significant differences at $(\alpha=0.05)$ attributed to the interaction.

\section{Discussion}

The results of the study indicated that the estimation of principals for male and female teachers of EL were high, this may be attributed to the fact that most of the principals are not specialized in EL, definitely their estimations for the academic domain. 
It seems to be that the principals concentrated on their estimations to the characteristics relating to the social, personality, and administrative domains more than academic domain because they are in touch with teachers in these domains. The results also showed that the estimations of principals for female EL teachers were higher than male teachers in all the domains except in social domain. On the one hand, this may be due to the fact that the female teachers are more committed to instruction more than male teachers; on the other hand, the female teachers are more committed to traditions and customs in Tafila Governorate more than male teachers who have much freedom to go outside home and to participate in social activities and occasions.

\section{Conclusion}

The results of this study showed that the estimations of the principals for EL teachers were high. The estimations for female EL teachers were higher than male teachers in all the domains except in the social domain.

\section{Recommendations}

- Such studies should be conducted to get accurate results for the academic domain taking the supervisors of EL views.

- New studies should be conducted to make sure that the curricula of EL are appropriate to the levels of students since the curricula are one of the components of teaching and learning process.

\section{Abbreviations: \\ EL: English Language \\ SD: standard deviation \\ FL: foreign Language \\ SDs: standard deviations}

\section{References}

Almaqtri, M. A. (2013). The qualities of a Good English Teacher as perceived by Saudi and Yemeni College students of English. Journal of Educational research, 3(2), 72-79.

Borg, S. (2006). The distinctive characteristics of foreign language teachers. Language Teaching Research, 10(1), 3-31. https://doi.org/10.1191/13621688061r182oa

Chireshe, R. (2011). Effective and ineffective lecturers: University students' perspectives in Zimbabwe. Anthropologist, 13(4), 265-269.

Dunton, J. (2001). Selection criteria used by high school principals in Virginia when hiring first year career and technical teachers. Doctoral dissertation, Virginia Polytechnic Institute and State University, Blacksburg.

Engel, M. (2013). Problematic Preferences? A mixed method examination of principals' preferences for teacher characteristics in Chicago. Educational Administration Quarterly, 49(1), 52-91. https://doi.org/10.1177/0013161X12451025

Harris, D. N., Rutledge, S. A., Ingle, W. K., \& Thompson, C. C. (2010). Mix and match: What principals really look for when hiring teachers?. Education Finance and Policy, 5(2), 228-246. https://doi.org/10.1162/edfp.2010.5.2.5205

Hoy, A. W., \& Hoy, W. K. (2012). Instructional Leadership: A research based guide to learning in schools $\left(4^{\text {th }}\right.$ Edition). Pearson.

Kalebic, S. C. (2005). Towards the development of standards in foreign language teacher preparation. Paper presented at $30^{\text {th }}$ ATEEA(Association for teacher Education in Europ) Annual Conference Amsterdam, Netherlands. Retrieved 1October 2016 from www.atee2005.n1/download/papers/05_ab.pdf

Koutsoulis, M. (2003). The characteristics of the effective teacher in Cyprus public high school: The students' perspective. Arlington, VA: American Association of School Administrators. (ERIC Eric document Reproduction Service. No(478 761).

Mertz, N.T. (2010). Teacher selection and school leaders effects. Journal of school leadership, 20(2), 184-207. 
Park, G., \& Lee H. (2006) The Characteristics of Effective English teachers As Perceived by High School Teachers and Students in Kores. Asia Pacific Education Review, 7(2), 236-248. https://doi.org/10.1007/BF03031547

Rutledge, S. A., Harris, D. N., \& Ingle, W. K. (2010). How principals "bridge and buffer" the new demands of teacher quality and accountability: A mixed-methods analysis of teacher hiring. American Journal of Education, 116(2), 211-242. https://doi.org/10.1086/649492

Shishavan, H., \& Sadeghi, K. (2009). Characteristics of an Effective English Language Teacher as perceived by Iranian Teachers and Learners of English. English Language Teaching, 2(4), 130-138. https://doi.org/10.5539/elt.v2n4p130

Zhang, O., \& Watkins D. (2007). Conceptions of a good tertiary EFL teacher in China. TESOL Quarterly, 41, 781-790. https://doi.org/10.1002/j.1545-7249.2007.tb00103.x 